Erly Wahyuni: Improving Students’ Low Class

\title{
IMPROVING STUDENTS' LOW CLASS PARTICIPATION IN SPEAKING ACTIVITIES BY USING DRAMA TECHNIQUE
}

\author{
Erly Wahyuni \\ Faculty of Teacher Training and Education, University of Muhammadiyah Malang \\ Korespondensi: Jl. Raya Tlogomas No.246 Malang Jawa Timur 65144 \\ Pos-el: erlywahyuni@ymail.com
}

\begin{abstract}
Abstrak
Sering kali pengajaran bahasa Inggris kurang mampu memenuhi tujuannya. Bahkan setelah bertahun-tahun belajar bahasa Inggris, peserta didik tidak mendapatkan kepercayaan diri untuk menggunakan bahasa di dalam dan luar kelas. Komunikasi yang nyata melibatkan gagasan, emosi, perasaan, kesesuaian dan kemampuan beradaptasi. Kelas bahasa Inggris yang konvensional hampir tidak memberikan kesempatan terhadap peserta didik untuk menggunakan bahasa dengan cara ini dan mengembangkan kefasihan di dalamnya. Dengan demikian, sayangnya, tujuan utama dari program pengajaran bahasa yaitu mengembangkan keterampilan dalam komunikasi, menjadi terabaikan. Sebuah alternatif yang menarik adalah mengajarkan bahasa melalui drama karena drama memberikan pengetahuan praktis tentang kekuatan bahasa yang ekspresif dan komunikatif. Dengan kata lain, hal tersebut mengintegrasikan aspek verbal dan non-verbal dalam komunikasi, sehingga menyatukan pikiran dan tubuh, dan memulihkan keseimbangan antara aspek fisik dan intelektual dalam pembelajaran. Selain itu, hal tersebut menumbuhkan kesadaran diri (dan kesadaran akan orang lain), harga diri dan kepercayaan diri, dan melalui hal ini, motivasipun tumbuh. Artikel ini bertujuan untuk melihat teknik drama dan beberapa kegiatannya yang dapat memotivasi siswa untuk berbicara.
\end{abstract}

Kata-kata kunci: partisipasi kelas, kegiatan berbicara, teknik drama

\begin{abstract}
Many a times the teaching of English language falls short of fulfilling its goals. Even after years of English teaching, the learners do not gain the confidence of using the language in and outside the class. Real communication involves ideas, emotions, feelings, appropriateness and adaptability. The conventional English class hardly gives the learners an opportunity to use language in this manner and develop fluency in it. Thus, the main purpose of the language teaching course, i.e., developing skills in communication, is unfortunately, neglected. An attractive alternative is teaching language through drama because drama provides practical knowledge of the expressive and communicative powers of a language. In other word, it integrates verbal and non-verbal aspects of communication, thus bringing together both mind and body, and restoring the balance between physical and intellectual aspects of learning. Furthermore, it fosters self-awareness (and awareness of others), self-esteem and confidence; and through this, motivation is developed. This article is aimed to look at the drama techniques and their activities that can motivate students to speak.
\end{abstract}

Keywords: class participation, speaking activities, drama technique 


\section{INTRODUCTION}

It is true that little in the formal process of teacher's training and education for foreign language teachers is designed to increase the knowledge of social and cultural context of communication. Linguistics and literary issues are the dominant focus in this process. The teachers to-be are also trained in methods and techniques of classroom management and content presentation of four basic language skills while at the same time they lack the right exposure and training of the role of culture in communication.

Language and literature are the product of culture. People use language to interact with other people and they write and read literature to enjoy it, because literary work depicts social reality. For a teacher who will employ literature in her/his English classroom, (s)he needs linguistic competence and literary competence as well. Lazar (2002) states that the latter may be relevant to language teachers wishing to use literature in their lessons. It is therefore argued that literature and language are two entities which intertwine each other.

Teachers often regard literature as inappropriate to language classroom. Savvidou (in Paran,2008) says that the reason lies in the common beliefs concerning literature and literary language. Firstly, the creative use of language in poetry and prose often deviates from the conventions and rules, which govern standard, non-literary discourse, as in the case of poetry where grammar and lexis may be manipulated to serve orthographic or phonological features of the language. Secondly, the reader requires greater effort to interpret literary texts since meaning is detached from the reader's immediate social context. Therefore, we need a concept to make teaching literature in foreign language classroom becomes essential in which teachers are concerned with the meaningful foreign language learning experienced by the students.

There has been an increasing interest in using literature in language classroom and how literature can be used with the language learners. Literature exposes learners to complex themes and fresh, unexpected uses of language (Lazar, 2002: 15). A good novel or short story may be particularly fascinating since it involves learners in suspense of uncovering the plot. With the literature materials for language learning being carefully selected, learners will feel that what they do in the classroom is relevant and meaningful to their own lives.

EFL teaching methods require more than the presentation of grammar and vocabulary lessons; they must also stimulate culcural awareness and critical thinking skills that students need to become fluent, successful English speakers who can handle advanced communicative activities.

Classical and modern literature has often been overlooked in the EFL classroom, especially regarding advanced EFL students. Research on the benefits of literature in language teaching extends back to the 1980s, when it was recognized that literature is conduit for improved critical thinking skills (Oster 1989). According to Van (in Paran,2009) literary texts are effective in promoting English language developments in all four skills "through interaction, collaboration, peer teaching, and student independence,". Other scholars have also remarked on the effectiveness of using novels as teaching tools in the ESL classroom (Paran 2008)

The use of literature in language teaching and learning offers some benefits. It provides learners with the access to the culture of the people whose language they are studying (Lazar, 2002, 16). Since 
language cannot be separated from culture, using literature in language classroom is then essential for the language learning itself. Literature helps learners in language acquisition. It is a fact that written materials are more available in language classes; therefore, literature may provide an appropriate context for processing and interpreting new language (Lazar, 2002: 17).

According to Lazar (2002: 89), novel is a literary work that involves a chronological sequence of events, linked by relations of causes and effect. The description of events in a novel is shaped by a narrator and the language of the novel is used in a highly self-concious way to convey particular effects. Using literary works in language teaching and learning provides some benefits especially if it does not require specific examination and there is time availability. According to Collie and Slater (2004: 3-6), the benefits that can be gained from using literature in language teaching cover the following things:

a. It provides valuable authentic material.

Literature offers abundant and various types of written materials. A literary work can be transcended in both time and culture as the reader in different country can read it at a different time. Literature is authentic in a sense that it is not designed for specific language teaching purposes. Recent language course materials have integrated many authentic samples of language in order for learners to be exposed to a language that is genuine and can be used in the classroom context. Literature is a valuable complement to such materials. In reading literary texts such as novels, short story or drama, students have also to cope with language intended for native speakers and thus they get additional familiarity with many different linguistic uses, forms, and conventions of the written mode.

b. It is the source of cultural enrichment.

Literary works such as a novel, a play, or short story offer a full and vivid context in which characters from many social backgrounds can be depicted. A reader can discover their thoughts, feelings, customs, etc. This vivid imagined world can quickly give the foreign reader the codes and preoccupations that structure a real society.

c. It functions as language enrichment.

It is believed that extensive reading increases a learner's receptive vocabulary and facilitates transfer to a more active form of knowledge. Literature provides a rich context in which individual lexical or syntactical items are made more memorable. Reading a substantial and contextualized body of text, students will gain familiarity with many features of the written language such as formation and function of sentences, the variety of possible structures, the different ways of connecting ideas which broaden and enrich their own writing skills. The extensive reading of a literary work develops the students' ability to make inferences from linguistic cues and to deduce meaning from context.

d. It offers personal involvement

Engaging imaginatively with literature enables learners to shift the focus of their attention beyond the more mechanical aspects of the 
foreign language system and it makes the learners eager to find out the plot of the story, feel close to certain characters and shares their emotional responses.

\section{INTEGRATING LITERATURE INTO LANGUAGE SKILLS}

The classroom activities which combine the use of literary texts and material development by learners to show how learner involvement can be maximized by engaging learners in meaningfully-designed tasks and the efficient exploration of literary texts.

Literature exposure in EFL will explore worldviews using information and knowledge of literary structures that appeal to and stimulate the students. It does not only focus on grammar and vocabulary, but also allows students to analyze and compare culturally diverse point of view, perspectives, and ways of describing the world through a basic literary analysis of a text.

\section{a. Listening}

The purpose of the activities is to sharpen students' listening ability in learning pronunciation different verbs forms, the distinction between long and short vowels (/i/ and /i:/, and so on. Students are provided with the text (poem or song) with those words missing. They can listen to the recording three times: the first time is purely devoted to listening and trying to work out what the missing words are; the second time deals with filling the gaps; and the third time consists of checking to confirm whether or not the answers are correct. The teacher then discusses the answers with the students and practices pronouncing the words with them through further listening to the tape.

\section{b. Writing}

Actually, writing skill offers an excellent opportunity for integrating language and culture because it can be controlled at various levels of difficulty. In addition, in writing, literary works constitute good model for narratives. By examining literary works, language learners learn about not only the grammar and vocabulary but also the writing mechanics and organization. They can see how correct punctuation is applied, how ideas, events and facts are organized into good paragraphs and finally how the paragraphs are combined into captivating stories. Whiteson (1996) presents techniques for teaching the paraphrasing skills using poems. Such an exercise is challenging and yet realistic because poetic language, though compact, is not easy to understand and thus paraphrasing will help students' understanding. The activity related to writing skill is by asking students to write down sentences or paragraphs based on the word or lyrics of the poem or other literary texts.

The next step is to help students understand more about the poem by engaging them in creative writing task which involve placing them into different roles related to the characters in the poem. For example, students may be asked to imagine themselves to be the parents and children in the poem. Each of them is to give response toward the poem written or orally. The parents will comment whether or not they will forgive them. The other half will pretend to be the children who tell them what they feel. Another writing activity can be done in groups. Each group will be asked to write on a sheet of paper the conflicts, which they can remember having with their parents.

Learners may be unable to replicate the whole session because designing creative writing task might be beyond their abilities. They can definitely work on the filling-in-the gaps task. To minimize the pressure, students may do it in groups. 
First, they have to choose a poem they like for the exercise. Then they decide which language items they want to practice (for example: vocabulary, noun, verb, adjective, pronoun, adverb and so on) and delete appropriate words in the poems. At the same time, teachers will need to give feedback to the students to make sure that what they have prepared suits the purposes, before they actually present their work to their classmates.

Based on the learners' work, teachers may build up more creative writing or grammar exercises. Working on their own materials, students find learning more interesting and motivating.

\section{c. Speaking}

Speaking activities can basically be performed under formal and informal (casual) circumstances. Therefore, it is better if speaking activities provide both opportunities for the students. In addition, speaking as an activity of verbal exchange is more frequently done in casual atmosphere and more verbal exposures are presented in this informal circumstance. The important thing in designing speaking (communicative) activities is that students have something to say. Students should be given ample opportunities both in formal or informal contexts to describe and give opinions about both native and target language cultural concepts.

Another way to furnishing speaking activities with culture exposure is by having students involved in simulations and role-playing that reflect both cultures. In such an activity, students can express freely their ideas in the construction of the dialogue in a low anxiety environment. This will naturally lead to a role-play exercise during which students can further stretch their imagination through exposure to other students' work. Stern (1991) held an opinion that literary work can also be used to enhance the learners' oral skills. At intermediate level, dramatization, improvisation and role-play of what they read in the literary work can improve the learners' oral skills.

\section{d. Reading}

This reading activity aims at developing the students' ability to comprehend the literal meaning of the poem, at the same time analyzing the message and tone. It may be more suitable for advanced students and can be done in groups. The teacher first provides the students with the text of a set of comprehension questions. The teacher then reads the text to the students and gives them some time to do the silent reading, focusing their attention on questions geared toward the surface understanding of the text. Students may work out the answers in groups in order to generate more conversation in English. Students should have a general understanding of the text after they have completed the comprehension exercise. The teacher then discusses the answer with the students, focusing on the development of the story of the text. The theme of the poem example may be introduced to the students, drawing their attention not only to the surface meaning of the poem but also to the message it carries. From the reading activities based on literary works learners not only improve their comprehension on explicit details or facts but also produce personal evaluations.

\section{e. Vocabulary and Grammar Activities}

Novel in the teaching of ESL or EFL can be used to develop learners' vocabulary as well as to improve their grammar. Stern (1991) states that literary texts can be used for developing learners' vocabulary. By asking learners to simplify, restructure, restate and 
paraphrase utterances, learners can improve their grammar.

The students were asked to read a novel. They also were asked to listen to the audio version of the novel to help them retain the words in their memory and understand the stories (words) through this audio exposure of the words. After that some students were assigned to read the paragraph of the chapters to the class. This is the additional word exposure to them. Next the students working in group were to discuss the selected words from the chapters by using the flow of the stories in the chapter to decide the part of speech and word meaning. They were encouraged to use context clues of the paragraph to understand the words and only referred to use the dictionary when necessary and to confirm their answers. The lecturer helped the students with the problems they got to solve. When they had already understood, they were asked to use the words in their own sentences individually.

Some students were appointed to write their sentences on the whiteboard and the class discussed whether the words were used correctly in the sentences. This was done to increase the students' knowledge of the part of speech and the word meaning and to improve their ability in constructing correct sentences.

\section{BENEFITS OF USING DRAMA IN EFL CLASS}

Using drama in the ESL classroom is not a new concept. Drama provides an excellent platform for exploring theoretical and practical aspects of the English language (Whiteson, 1996). The improvisation aspect of drama gives students opportunities for developing their communicative skills in authentic and dynamic situations. By using drama in the English classroom, we can use English with our students in intriguing and useful ways. The language can be used in context and makes it come to life. Drama has the potential of making the learning experience fun for the students and even memorable because it is interactive and visual.

There are many studies about using drama to learn English. Wan Yee Sam talks about the communicative approach, drama techniques, value of drama in education, advantages and disadvantages (Sam,1990). Maley and Duff are classic sources for the benefits of using drama techniques; how it helps to learn new vocabulary, builds confidence, motivates the students and helps shift the focus from the teacher to the students (Maley,2005). Drama is a special communication situation which makes considerable demands on the flexibility and skills of the teacher (Kao, 1998). We have Morrow (1981) who gives some guiding principles behind the use of the communicative activities. Holden (1981) adds some definitions as to what drama is and how it provides opportunities for a person to express them. The personal nature of improvisation provides many outlets for self-expression. We even hear that children need to play as an important developmental process.

Drama puts the teacher in the role of supporter in the learning process and the students can take more responsibility for their own learning. Ideally, the teacher will take a less dominant role in the language class and let the students explore the language activities. In the student centered classroom, every student is a potential teacher for the group. Creative drama will offer exercises in critical thinking and the chance for the students to be creative. A good example of this is role-plays in small groups The ESL/EFL group will have many situations where they can develop their own ideas as 
well as skills of cooperation when interacting with classmates. The group work builds social awareness and understanding as we walk in the 'shoes of another'. Drama gives an excellent method for studying human nature and working in harmony. The play-acting provides the opportunity for a healthy release of emotion in a safe setting which can work to relieve the tension of learning in a second language.

\section{a. Drama Brings Literature to Life}

Most teachers see the value of drama in offering training in speech. What is not obvious is how even abstract learning is easier when acted or demonstrated. Drama can also be used to bring literature to life for the students. It is more dynamic than simple text and helps the visual learners as well as recycles new vocabulary. While drama does have a characteristic of recreation, the fun aspect should not be under-estimated. When the students are enjoying an activity, they are learning and letting their guard down. The shyness and fear of using English very often blocks learning. When the students are submerged in an active fun activity, they are more open to new concepts and learning will occur. When the students are having fun, they let their second language guard down and become less inhibited. The student will tend to relax and stop blocking out the new language. They will forget how hard it is and start absorbing the ideas presented. Changing the students' perception of the language learning from a negative to a positive is a huge plus for the learning

process.

\section{b. Drama as a Powerful Teaching Tool}

In the ESL/EFL classroom, roleplaying is a powerful tool. It teaches cooperation, empathy for others, decisionmaking skills and encourages an exchange of knowledge between the students. These aspects alone make role-playing beneficial because the students are learning from each other. Yet, there are many other positive aspects to the role-playing. Apart from the obvious development of communication skills, it encourages leadership, team work, compromise, authentic listening skills and practice with real life savior-faire. However, it does not stop there. It teaches cooperation, empathy, develops decision making skills, promotes the exchange of knowledge, builds confidence and selfesteem, refines presentation skills, encourages self-acceptance and acceptance of others, features of empowerment, pride in work, responsibility, problem solving, management and organizational skills, begets creativity and imagination.

A good drama teacher can use the practice with role-playing to contribute to the self-esteem of the students, build their confidence in using the target language (English) as well as develop many of the skills mentioned above which will carry over to real life. It is certain that selfacceptance can be encouraged in subtle ways and acceptance of others. Drama has the potential to empower the students, give them many opportunities to have pride in their work, it teaches them responsibility, problem solving, management and directing proficiencies. The many activities of team work force students to develop organizational skills and to think on their feet. These tools can be used in all aspects of their lives. These skills will be useful in the future job market when the students need to work with others or even in the future job interview when the potential employer asks an unexpected question and you need to think quickly. 


\section{c .Drama Reveals Aspects of the Human Condition}

When you think about it, drama is a method to reveal aspects of the human condition; life is nothing more than a grand series of improvisations (Price ,1980). Through the games, the students begin to realize the importance of shared space, time, attention, information and ideas. The games spark spontaneity and minimize self-consciousness, which often inhibits learning. The games are also good for developing concentration and trust in the classroom. While the students are having all this fun, they are developing skills of coordination, imitation while focusing on the task. The improvisation enables the students to flex their emotional, mental as well as physical muscles in a safe and controlled setting. A good example of this was a role-play one group performed where they displayed their displeasure with the school principal. There was no harm done and all the students were feeling the same.

\section{ACKNOWLEDGEMENTS}

We would like to thank the journal editor of Bahasa \& Sastra for publishing this research article, and also thank to those who have helped this research.

\section{REFERENCES}

Collie,J., \& Slater. 2004. Literature in the language classroom. Cambridge: Cambridge University Press.

Holden, Susan. 1981. Drama in Language Teaching. Essex: Longman.

Kao, Shin-Mei \& O’Neill, Cecily. 1998. Words Into Worlds, Learning a Second Language through Process
Drama. Stamford USA: Ablex

Publishing corp.

Lazar, Gillian. 2002. Literature and

Language teaching: A Guide for teachers and trainers.

Cambridge: Cambridge University Press.

Oster, J. 1989. TESOL Quarterly 23 (1): 85103. Seeing with different eyes: Another view of literature in the ESL class.

Paran, A.2008. The role of literature in instructed foreign language learning and teaching: An evidence-based survey. Language Teaching 41 (4):465496 .

Stern, Susan L.1991. An integrated approach to literature in ESL/EFL in teaching English as a second orfForeign language (2nd Edition) edited by Marriane Celce-Murcia). New york: Newbury House,pp.328-345.

Maley, Alan and Duff, Alan. 2005. Drama techniques in Language Learning. Cambridge: Cambridge University Press.

Morrow, Keith. 1981. Principles of communicative methodology. In: Johnson, Keith Morrow, Keith (eds.): Communication in the Classroom. London and New York: Longman.

Price, Pamela. 1980. Creative Play Production in the Classroom. Yale: Yale Publishers.

Sam, Wan Yee .1990. Drama in Teaching English as a Second Language- a Communicative Approach. The English Teacher, vol. 9, July 1990. Malaya.

Whiteson, Valerie.1996. New Ways of Using Drama and Literature in Language Teaching. Alexandria,VA., $\quad$ TESOL. 